\title{
Designing a Retail Store Environment for the Mature Market: A European Perspective
}

\author{
Ann Petermans, M.S. and Koenraad Van Cleempoel, Ph.D., PHL University College, Belgium
}

\begin{abstract}
This article discusses elderly consumers' physical and social needs and wants in the marketplace, and presents case studies of two European food retail stores, which were designed to meet these concerns. The authors review information on the elderly consumers' segment and discuss literature on retail design and retail branding, and question how designers should be more aware of multiple modes of interpreting brands, given generational differences and the existence of various types of retail settings. Given that the physical and social aspects are considered key to improving the shopping experiences of elderly consumers, the authors also review literature that focuses on the importance of creating efficient, user-friendly, and aesthetically pleasing shopping environments, which pay particular attention to intangible social aspects. Older consumers' consumption satisfaction does not come merely from consuming for gathering tangible possessions, but from consuming while seeking intangible experiences, such as feeling welcome in a retail store (Kim et al., 2005; Sherman, Schiffman, \& Mathur, 2001). The authors contend that retail stores, properly designed to meet the needs and wants of the mature market, can strongly enhance this consumer segment's shopping experiences.
\end{abstract}

The article concludes with the presentation of two case studies of "senior supermarkets" in Europe. By investigating how these stores pay attention to physical and social aspects, which older consumers value as important, the authors analyze to what extent both stores are truly retail environments, adapted to the needs and wants of the mature market.

\section{Introduction}

One of the main features of the current world population is the growing number of elderly people (often defined as people aged 65 years and older) (Gabriel, 1990a; United Nations, 2007). Due to changes in fertility and mortality rates, improved health care and changes in lifestyle, the world population has changed and will continue to change in the future. Looking at the European population composition, recent predictions make clear that by $2020,20 \%$ of the European population will consist of people aged $65+$. By 2050, this number is expected to increase to almost 30\% (Giannakouris, 2008). Statistics highlight Southern Europe and Germany as the strongest growing poles (Arabaci, 2008). This ongoing demographic shift creates opportunities and challenges for marketers, retailers, designers, and consumer researchers alike.
However, research on shopping experiences of elderly consumers is relatively rare. Most of this work is carried out in North America and concentrates on shopping experiences, patronage behavior, and the identification of store attributes elderly people value as important (Bartos, 1990; Burt \& Gabbott, 1995; Curch \& Thomas, 2006; Lumpkin \& Greenberg, 1982; Lumpkin \& Hite, 1988; Moschis, 2003; Stroud, 2005; Szmigin \& Carrigan, 2001). However, differences in culture are likely to result in different shopping experiences and ultimately different consumer responses within the mature market (Burt \& Gabbott, 1995). Because the actual shopping experiences, needs, and wants of the elderly consumer in many European countries remain largely uncharted (Weijters \& Geuens, 2003), the purposes of this article are to (1) explore issues related to the design of a retail environment for the mature market through a literature review; (2) present case studies of two European food retail stores that were designed to 
PETERMANS AND VAN CLEEMPOEL

... [European] food retail stores, properly designed to meet the needs and wants of the mature market, can strongly enhance this consumer segment's shopping experiences.

meet the needs of older consumers; and (3) describe and discuss the implications of these approaches for both retail and interior designers.

The opening section of the article begins with a review of current literature on the elderly consumers' segment. The second section discusses literature on retail design and retail branding and the question of how designers can become more aware of multiple modes of interpreting brands, given generational differences and the existence of various types of retail settings. The third section reviews existing academic literature on elderly consumers' needs and wants in the marketplace. The final section begins by describing the growth and design of European supermarkets and concludes with two case studies of "senior supermarkets" in Europe. It argues that food retail stores, properly designed to meet the needs and wants of the mature market, can strongly enhance this consumer segment's shopping experiences.

\section{Literature Review}

\section{Today's Mature Market}

\section{Different from Previous Generations}

Today's "silver shoppers"1 are different in comparison with elderly consumers of previous generations (Mathur \& Moschis, 2005; Szmigin \& Carrigan, 2001). The vast majority of people aged $65+$ want to enjoy life as long as they can, stay active, continue to consume, and start to enjoy experimenting with new technologies (Balazs, 1994; Brock, n.d.). This is also true for the baby boomer generation (people born between the years 1946 and 1964) (Greer Huss Pace, 2006). Baby boomers and people aged 65+ share an increased tendency to retire earlier, and thus, to have more leisure time, to be used for shopping and spending (Balazs, 1994; Buck, 1990; Greer Huss Pace, 2006; United Nations, 2001). Given that a significant proportion of people of this age group appear to have high disposable income and low debt rates, ${ }^{2}$ it is clear that this consumer segment presents a highly interesting opportunity for retailers.

\section{Segmenting the Mature Market}

Although in the remainder of the article the group of silver shoppers will be considered in its entirety, it is also important to note that as a group the mature market is just as diverse as other age groups. Indeed, various types of elderly consumers shop somewhat differently for diverse product types and have somewhat different needs and wants in the marketplace (Hare, 2003; Moschis, 1992). Academic literature on segmentation strategies to identify these different subgroups is readily available (Balazs, 1994; Bone, 1991; Mathur \& Moschis, 2005; Moschis, 2003; Oates et al., 1996; Sherman, Schiffman \& Mathur, 2001; Stroud, 2005).

Demographic Segmentation

Although "chronological age" appears to be the easiest way of segmenting older consumers, in most cases, it is probably the least effective variable because it does not correlate well with behavior (Gabriel, 1990b; Moschis, 2003; Myers \& Lumbers, 2008; Stroud, 2005). Oates et al. (1996) indicate that demographic data does not give a complete image of the consumer. Instead, they propose "psychological age"3 as a segmentation variable, referring to the response people give when being asked "how old do you feel?" After all, elderly people can be chronologically old without actually feeling old. By adding such psychological information to demographic data, a marketer will be able to better understand consumers (Oates et al., 1996).

Psychographic Segmentation

Psychographic segmentation entails segmenting the market based on people's lifestyle, personality, or values (Kotler, 2001). Moschis (1996, 2003) articulated gerontographics as a concrete psychographic segmentation variable. He discovered that older people's behavior is sensitive to their needs and lifestyles, which are influenced by the life-changing events and circumstances they experience. This segmentation method takes the aging process and the person's life experiences into consideration. According to Moschis, these variables change when people get older and often say a lot more about a person than his 
Tangible retail design concerns the usage of fixed, material cues in the design of the store, which can affect consumers' . . Intangible retail design elements, on the other hand, refer to the use of immaterial cues, which also can influence consumers' opinion.

or her demographic age. Aging therefore often results in changes of consumer's needs for and perceptions of products and services and consumer's responses to marketing stimuli.

Despite Moschis' work, there is no accordance among different authors about the selection of variables, which can be considered as psychographic segmentation variables (Ahmad, 2003).

Other Segmentation Criteria

Besides segmenting the mature market by demographic and psychographic variables, segmentation by income, gender, geography, education, health, social-professional activity, and dependence are possible (Burnett, 1996; Stroud, 2005; Weijters \& Geuens, 2003). Furthermore, retailers could benefit from understanding the shopping orientation of older consumers. In the study on aging consumers (people aged 50 and older), Balazs (1994) makes a distinction between recreational and functional (or economic) shoppers. Recreational shoppers are people who like to shop, and consequently shop significantly longer and more frequently than functional shoppers. They also seem to spend more money than functional shoppers. Functional shoppers just shop for what they need and are not interested in other aspects. Since Balazs' study pointed out that $70 \%$ of her respondents could be categorized as recreational shoppers, this consumer segment provides great potential for retailers and designers alike.

After having described today's mature market and strategies for segmenting that market, the next section discusses literature on retail design and retail branding.

\section{Retail Design and Retail Branding Retail Design}

"Retail design" is a fast emerging discipline in the field of interior design. The term "retail design" covers several aspects that need to be considered when designing retail stores, interiors, and layout. First, retail design encompasses an understanding of what will work aesthetically within the retail environment. This includes comprehending the importance consumers attribute to tangible and intangible design elements in the store. Tangible retail design concerns the usage of fixed, material cues in the design of the store, which can affect consumers' perception and experience of the store. Examples of tangible retail design elements are the store frontage, carpeting, and fixtures. Intangible retail design elements, ${ }^{4}$ on the other hand, refer to the use of immaterial cues, which also can influence consumers' opinion on and evaluation of the store. An example of this is a multisensory experience, including music (sound), scents (smell), colors (sight), and crowding (touch) (Kotler, 1973). But making a clear distinction between tangible and intangible retail design is not clear-cut. Lighting, for instance, clearly balances on the borderline between both types of retail design. Lighting demands certain material design elements (tangible retail design), but undoubtedly also influences the retail store's atmosphere (intangible retail design). Likewise, to the authors' point of view, the question if tangible or intangible retail design weighs heavier in the customer's perception and evaluation of the store will be answered differently by various retail designers.

Secondly, retail design demands an understanding of the different aspects of the store concept, including how it would perform functionally and commercially. Applied to lighting, for instance, a designer should reflect not only on the practicality, effectiveness, and sustainability of the designed lighting plan, but also on the commercial possibilities the proposed lighting plan has to offer. For instance, will the lighting make it possible to highlight specific zones in the store or specific products on particular shelves? Past research (Areni \& Kim, 1994; Summers \& Herbert, 2001) on this matter has illustrated that the consumer is drawn to products that are illuminated individually, in preference to those that are lit by general lighting.

Thirdly, choosing to invest in retail design involves a certain cost. Thinking about designing a retail store evidently includes thinking about how the store's design can be built to the stipulated budget (Kindleysides, 2007). With only a limited budget at 
Concerning older consumers, past research has showed that most silver shoppers highly value good in-store service and seem to particularly appreciate intangible experiences in retail stores.

hand, choosing to develop a retail design by focusing on intangible design aspects (or so-called atmospheric variables) already offers possibilities. For instance, Turley and Milliman's review article (2000, p. 193) on the effects of atmospherics on buyer behavior indicated that "atmospheric variables influence a wide variety of consumer evaluations and behaviors."

A final factor which needs to be considered when designing a retail store is the fact that retail design should meet all relevant regulations concerning the use of a public space (Kindleysides, 2007).

Consumers in today's retail stores ask and expect more than just being satisfied with the purchased brand or product: they look for value. Therefore, value creation is, increasingly, seen by many authors as the key to long-term retailer success (Babin \& Attaway, 2000; Sweeney \& Soutar, 2001). A retailer can strive to create value by building personal, intuitive relationships with consumers, in order to make them feel allied with the brand or retail store (Pine \& Gilmore, 1999, 2008). When trying to reach this goal, retailers need to be aware of the importance of designing retail environments that create personal and memorable customer experiences. Concerning older consumers, past research has showed that most silver shoppers highly value good in-store service and seem to particularly appreciate intangible experiences in retail stores (Bone, 1991; Kim et al., 2005; Myers \& Lumbers, 2006; Sherman, Schiffman, \& Mathur, 2001). Appropriately matching the design of a retail store environment with the needs and wants of its target group has shown to influence consumers' enjoyment and memorability of the retail store (Chu \& Lam, 2002). Pleased consumers will continue coming back to the store; hence, creating a loyal consumer public is the ultimate retailer goal. Focusing the design of a retail store environment on the creation of memorable experiences is therefore a possible differentiation strategy which seems particularly interesting for the mature market.

\section{Retail Branding}

Retail branding concerns a brand's and retail store's specific representation. It starts with people's mental image of a brand or retail store and their impression of a particular product and the type of store they would like to buy it in. It concludes with the feeling they get when visiting the actual retail store, where they are surrounded by products, personnel, and other customers. Consequently, "retail branding should represent the identity and ambition of the company, in the spirit of time" (Van Tongeren, 2004, p. 66).

Developing the store name into a strong brand has become a competitive advantage for the market, because successful retail branding can create brand preference. Brand preference, in turn, ultimately results in customer loyalty. In today's economy, customers need to be the focal point of retailers' and retail designers' interest and work field. Customers no longer want to be viewed as simple product buyers, but as people with true and authentic desires, feelings, and personalities. When customers consider a retail store to take care of their individual needs and wants successfully, they will want to return to the store. Hence, given that the ultimate goal of retail branding is "customer binding" (Van Amerongen \& Christiaans, 2004; Van Tongeren, 2004), the number of retail store environments striving to achieve this goal is on the increase (Myers \& Lumbers, 2008). Given that older consumers value available product assortment as less important than experiences (Bone, 1991), retail stores succeeding in committing silver shoppers to their store by communicating "correctly" with the mature market can differentiate from competitors (Myers \& Lumbers, 2008).

The principles of retail design and retail branding can be applied to a wide variety of retail settings (supermarkets, convenience stores, etc.). However, according to Van Ossel and Versteylen (2003), implementing retail branding as a differentiation strategy is a method which is being used more often by different store types (e.g., supermarkets vs. convenience stores) than by individual store brands. Yet, classifying different retail stores and shopping centers is rather complicated. Guy (1998a) reviewed different methods in classifying retail outlets and areas: classification by type of goods, by shopping trip purpose, by size and type of store, and by store ownership. He states: "it 
PETERMANS AND VAN CLEEMPOEL

Research shows that for older consumers, it is important to create efficient and user-friendly shopping environments with special attention to the concrete physical and spatial aspects of the shop.

would be incorrect to insist that one system of classification should be used in preference to another" (Guy, 1998a, p. 263).

\section{Retail Design and Retail Branding: Closely Connected}

When consumers visit a retail store, they immediately make an association between the products sold in the store, their price, the store's "tone of voice" and ambience, and the retailer's presence and identity. As a result, retail design and retail branding cannot be disconnected from one another (any more). The role of retail design is to translate and develop retail branding into the practice of a retail store environment, in accordance with specific societal and temporal conditions (Van Tongeren, 2003, 2004).

In today's world where homogenization of products and services is widespread, retailers and manufacturers are continuously on the lookout for differentiation strategies. Since it is being accepted that a physical retail environment can have as much effect upon the consumer's perceptions as the quality of the product(s) itself (Underhill, 1999), it is of growing importance for retailers to be on the same wavelength as their consumers.

Applied to silver shoppers, understanding who the store's consumers are and what particular functional, ${ }^{5}$ social, and emotional ${ }^{6}$ characteristics they like and dislike in the store can help retailers and store managers in developing a proper brand strategy for the retail store. In addition, it can help designers to design retail stores in such a way that silver shoppers are at ease with their surroundings and want to keep coming back. Applying the brand strategy to design practice in the correct manner will help the store to create a more successful retail environment (Brigham, 2005).

\section{Designing a Retail Store Environment for the Mature Market: Points of Interest}

This section focuses on two issues involved in the design of a retail store environment which are considered key to improving shopping experiences of elderly consumers. First, the importance of the physical and spatial aspects of the retail store environment is studied. Secondly, the emphasis the mature market places on the social aspects of the retail store is discussed.

\section{Universal Design: Importance of Physical Aspects in the Retail Store Environment}

In the first section of the literature review, the authors first discussed the heterogeneity of the mature market and next described different approaches for segmenting this consumer group. When designing retail store environments to appeal to as many silver shoppers as possible, retailers and designers should strive to create "universally designed" stores. ${ }^{7}$

Implementing "universal design" features in the design of retail stores would enable older consumers to function optimally and comfortably in these environments. However, the concrete realization of this type of features should be subtle and not stand out (Armstrong, 2005). Creating a successful "adaptive" retail store environment requires the application of design features that formulate answers to consumers' needs (Hunt, 1992). Research shows that for older consumers, it is important to create efficient and userfriendly shopping environments with special attention to the concrete physical and spatial aspects of the shop (Curch \& Thomas, 2006; Meneely et al., 2009; The Consumer Council, n.d.). Some typical concerns of silver shoppers in this area designers should pay attention to are mentioned in Table 1.

Given that silver shoppers, in general, buy a lot of the same things as younger people, Underhill (1996) states that in appealing to this target group, product mix may be less important than the store's physical features. Retailers and the retail industry, however, often share the concern that changing a retail space to appeal to older shoppers may deter shoppers of younger age groups. Greer Huss Pace (2006), however, is convinced that designing accessible and aesthetically pleasing retail environments will not avert customers from other age groups. 
Despite the clear benefits of functional, accessible, and aesthetically pleasing shopping interiors, a systematic review of literature . . . also indicated that the store's social environment and the experiences it offers may well be of equal importance to older consumers.

Table 1. Physical aspects silver shoppers value as important

\begin{tabular}{|ll|}
\hline External store environment & Internal store environment \\
\hline Is it easy to get to the store (by car, by bus)? & Store layout: where are the needed products placed in the shop? \\
What is the distance from the parking lot to the store? & Does the shop have rest areas? \\
Is it possible to easily maneuver between the aisles? & Are the trolleys easy to steer? \\
& What is the shelves' height? \\
& Is the lighting bright? \\
& Is the store equipped with non-skid floor? \\
& Are the product labels and price tags clearly displayed? \\
& Is the detailed information, mentioned on the product label (e.g., \\
cooking instructions, nutritional details), easily readable?
\end{tabular}

\section{Experience Economy: Importance of Social Aspects in the Retail Store Environment}

Despite the clear benefits of functional, accessible, and aesthetically pleasing shopping interiors, a systematic review of literature on the shopping behavior of older consumers also indicated that the store's social environment and the experiences it offers may well be of equal importance to older consumers.

Thinking about how a retailer can understand what appeals functionally and emotionally to older consumers brings us to the concepts of "customer experience" and "experience economy."

The concept "customer experience" was coined in 1982 by Holbrook and Hirschman as a new experiential approach to consumer behavior. The importance of various variables, which were neglected until then were re-considered (e.g., the role of emotions in behavior). However, it was not before 1999 when this concept came to the fore in the management discipline, in Joseph Pine and James Gilmore's book The Experience Economy: Work Is Theatre and Every Business a Stage. Since economics (and marketing) are progressing from a goods to a service dominant logic (Vargo \& Lusch, 2004), inducing "experiences" has become a means of communication as well as a possible differentiation strategy. In the current experience economy, consumers look for personal, intuitive relationships with brands and retailers (Pine
\& Gilmore, 1999, 2008). By means of an experience, not only consumers' rationale but also their emotions are being addressed. Since experiences are important in the present market logic, designing retail environments (for instance for the mature market) should be directed toward creating retail atmospheres that produce memorable and personal customer experiences. Retail designers today need to focus on expressing experiences, not only in the interior and spatial sense, but also in the communicative and visual sense (Van Amerongen \& Christiaans, 2004).

Various authors (Kim et al., 2005; Sherman, Schiffman, \& Mathur, 2001) explained how older consumers' consumption satisfaction does not come from consuming for gathering (tangible) possessions, but from consuming while seeking (intangible) experiences, such as having a friendly conversation or enjoying the ambience. Among other things, silver shoppers show a particular appreciation for "value" in a store (Meneely et al., 2009; Moschis, 2003; Underhill, 1996). They want to feel "welcome" and appreciate good service and personal interaction from the personnel (Mogelonsky, 1995). Burt and Gabbott (1995) showed that silver shoppers may also engage in shopping as a means of socializing with their friends. This was confirmed by Moschis (2003), Wilson et al. (2004), and Meneely et al. (2009). Graham et al. (1991, mentioned in Curch \& Thomas, 
2006) noticed that for two-thirds of their respondents, going to a shopping center was a free time activity and the shopping center was a place for social contacts. Recently, Myers and Lumbers (2008) came to the same conclusion. Kim et al. (2005) indicate that for people aged 55 or older, retail store environments are considered as places for reducing loneliness. Schiffman and Sherman (1991) concluded that when marketers want to be successful with older consumers, they increasingly have to emphasize experiences related to shopping motivation.

When creating and directing experiences, retailers and retail designers must always keep in mind that the retail experience needs to deliver value to consumers, since perceived value is being characterized as the essential outcome of marketing activity (Mathwick et al., 2001). When a retail experience succeeds in delivering this value, it can become the key to longterm success (Sweeney \& Soutar, 2001). However, retailers and designers cannot neglect the importance of functionalities: empirical research on customer experiences showed that consumers (in all age groups) seek an adequate balance between utilitarian (functional) and experiential (hedonic) values (Fiore \& Kim, 2007; Gentile et al., 2007). This is also true for the mature market: older consumers are more likely to return repeatedly and become loyal if they are satisfied with the store's concrete product and service offer, in-store atmosphere, and potential instore experiences (Bloemer \& de Ruyter, 1998).

Economy (and marketing) will continue to evolve in the future. Where is the experience economy going to?

At the beginning of the twenty-first century, different authors started to criticize the company-centric approach of Pine and Gilmore's original concept of the experience economy. This business model seemed to have propelled (over) commercialization and consumerism.

Increasingly, consumers in the twenty-first century do not want to be considered any longer as mere "consumers"; they want to achieve goals in life, realize ideals, and contribute to aspects they value as important (Nijs \& Peters, 2002). As mentioned before, silver shoppers particularly fit in this profile, since their consumption satisfaction does not come from (mere) consuming for gathering (tangible) possessions, but from consuming while seeking (intangible) experiences. Consequently, instead of the top-down approach as practiced in the first generation experience economy, consumers increasingly start communicating with companies about what they want to "experience"; through dialoguing, both parties search for the best possible solution. In this so-called second generation experience economy, the dialogue between consumers and businesses forms the basis for the co-creation of values (through experiences) which are meaningful and truly unique for the individual customer (Prahalad \& Ramaswamy, 2004).

\section{Supermarkets for the Mature Market: Two Successful European Case Studies}

After having explored theoretical issues, related to the design of a retail environment for the mature market in the previous section, this section presents case studies of two European food retail stores that were designed to meet elderly consumers' physical and social needs and wants in the marketplace. Taking the present body of knowledge into account, how can the design of retail stores be adapted to meet older consumers' needs and wants? To the best of the authors' knowledge, no academic research literature has tried to answer this question before.

The authors decided to focus on food retail stores in their case studies. In response, this section starts with discussing the growth and design of food retail stores in Europe. Next, the case study method used for selecting, analyzing, and discussing two "senior supermarkets" in Europe is described. This method was chosen because it provides a systematic protocol for viewing the problem, collecting and analyzing the information, and reporting the outcome (Yin, 2002). 
PETERMANS AND VAN CLEEMPOEL

Over the last few years, the European retail industry has been characterized by a major wave of internationalization. This has allowed large retail companies to penetrate countries where access was difficult.

\section{Growth and Design of European Supermarkets}

As discussed in the introduction, several European countries are experiencing analogous demographic and socio-economic trends. Despite the omnipresence of these trends, European retailing still shows significant national differences. Colla (2004) identified four factors to explain these differences: changes in consumer behavior, different retailing legislation, technological progresses, and the influence of the internationalization process.

Examples of elderly consumers' concerns, which have become increasingly important throughout Europe and which should be considered by retailers and designers, were discussed in the section "Designing a Retail Store Environment for the Mature Market: Points of Interest." Colla (2004) predicts that large retail formats, whose strategy is essentially based on competing on large volumes, will face increasing difficulties to adapt to the changes in customers' needs and wants, in particular in countries where their format is dominant. Keeping track of and investing in technological developments can, however, allow retailers to collect valuable information on, for instance, trends in consumer purchasing habits and product sales. Knowledge of and interest in using this data offers possibilities for retailers and designers to develop a more personal, intuitive relationship with customers by taking care of and trying to formulate answers to concrete consumers' needs and wants in the marketplace. Adaptations retailers can make to their retail formulas are evidently always influenced by the existing retailing legislation. Changing the legislative rules of competition allows states to encourage corporations to develop certain retail formats rather than others (Guy, 1998b). It can also facilitate or limit the possibilities for corporations to create so-called economies of scale. This can be achieved by focusing on acquisitions or creating joint-ventures or mergers with competing supermarket holdings. Over the last few years, the European retail industry has been characterized by a major wave of internationalization. This has allowed large retail companies to penetrate countries where access was difficult (Colla, 2004).
Hence, some European market leaders have emerged, such as Carrefour, Tesco, Edeka, and Tengelmann. Although the existing cultural and socio-economic differences throughout Europe have restrained these large retailers from developing truly pan-European retail strategies, today's European market leaders have been able to successfully penetrate a limited number of countries, which are situated in a homogeneous geographic and cultural zone. In Germany, for instance, a country which is known for the presence and success of hard discounters, discount stores such as Edeka have proven to be successful in exporting their retail formulas to countries bordering Germany (for instance, Austria). According to Colla (2004, p. 65), the survival of retail formats and formulas throughout Europe "implies continuous transformation to adapt to consumers' new expectations. In food retailing, significant transformations in all retailing formats will take place and new formats will appear, after the deployment of new strategies of differentiation of the offer and innovations in terms of the product mix, layout and atmosphere in the stores."

Concerning the design of today's supermarkets in Europe, the authors contend that most specifically emphasize the functionality of the retail space and the way the shopping environment is organized. In grocery retailing, pricing of products, shopping convenience, choice, and speed of shopping indeed remain very important concerns for customers, which retail designers should account for when designing these kinds of interior spaces. However, the rise of the experience economy has made clear that despite the obvious benefits of functional, accessible, and aesthetically pleasing shopping interiors, older customers seem to value a store's social environment and the experiences it offers in particular. Designers and grocery retailers therefore should strive to balance functional and "experiential" concerns when designing retail spaces, appealing to consumers with different shopping motives (Esbjerg \& Bech-Larsen, 2009).

In the next section, we describe two case studies of supermarkets which have explicitly implemented this balance in their designs. 


\section{Case Studies: “Senior Supermarkets” in Europe}

The selection of the case studies was based on different criteria. First, Burt and Gabbott (1995) indicate that clear behavioral differences exist between food and non-food shopping behavior of elderly consumers. Of primary concern to this study, however, is research into the food-shopping activities of the mature market, because recent figures indicate that European households in general dedicate almost 20\% of the available household budget to food, beverages, and tobacco (Eurostat Press Office, 2008). Since another third of the available household budget is dedicated to housing, $12 \%$ to transport, and $8.4 \%$ to culture and recreation, ${ }^{8}$ it is clear that food shopping represents an important household expenditure. Looking specifically at the situation of elderly consumers in Europe, recent analyses pointed out that this consumer group in general dedicates $17.4 \%$ of their available household budget to food, beverages, and tobacco (45- to 59-year olds). For consumers aged more than 60, this percentage increases to $18.4 \%$ (Borg, 2009).

Second, given that $80.2 \%$ of over 50 -year olds frequently shop in supermarkets (Arnold \& Krancioch, 2008) and elderly consumers prefer to shop in a pleasant retail environment (Schmidt et al., 1994), the authors decided to focus on food shopping in supermarkets. Third, because the research focused on the European retail situation, examples of supermarkets in different European countries were searched for. Fourth, the supermarkets had to be specifically designed to meet the needs and wants of older consumers. Presentations and marketing materials from the initiating grocery retailers, diverse popular press and journal publications regarding this new retail concept supported the decision on this matter. Fifth, availability of information on these supermarkets influenced the selection. Data collection for the empirical inquiry was done initially by searching online and in specialized professional journals, using the search terms "supermarkets for elderly," "senior friendly supermarkets," "store senior shoppers," "aging population Europe + supermarket," "pensioner-friendly supermarket," and "supermarket for pensioners."
Next, communication and public relation managers of supermarkets about which data had been collected were contacted by mail in order to gather additional information from primary sources. Lastly, the authors decided to select supermarkets that had already proven their success in the mature market, as the alterations in design and available products and services these stores have implemented can serve as concrete illustrations of the points of interest, discussed in the review of literature. "Success" was measured by looking at the turnover the selected retail stores realized after altering the store's design to meet the mature market's functional and social needs and wants. Data, published in annual reports from supermarket chains and publications in professional journals were used as input for this criterion.

Taking these selection criteria into account, "Adeg Aktiv Markt 50+" and Kaiser's "Generations Market" were selected.

Both descriptive case studies were analyzed relying on the points of interest, discussed earlier in this article in the review of literature (Yin, 2003, 2009). An evaluation scheme was designed to comprehensively judge both supermarkets against the theoretically discussed points of interest.

\section{Case Study 1: Adeg Aktiv Markt 50+}

The first retail case study looks at the successful senior supermarkets of the Edeka chain in Austria and Germany. Since a quarter of the Austrian and a third of the German population are expected to be 65 or older by 2015 (Arabaci, 2008), the opening of the "Adeg Aktiv Markt 50+" in 2003 in Salzburg was the first attempt by Adeg, a subsidiary (at that moment) of the German retailer Edeka, to formulate an answer to the challenge of the graying population (Anderson, 2003).

"Adeg Aktiv Markt" is the chain's smaller, urban format. "Adeg Aktiv Markt 50+" specifically was designed to meet the needs and wants of the mature market. 


\section{Figure 1. Edeka's Supermarkt der Generationen (used with permission from Edeka and Tengelmann).}

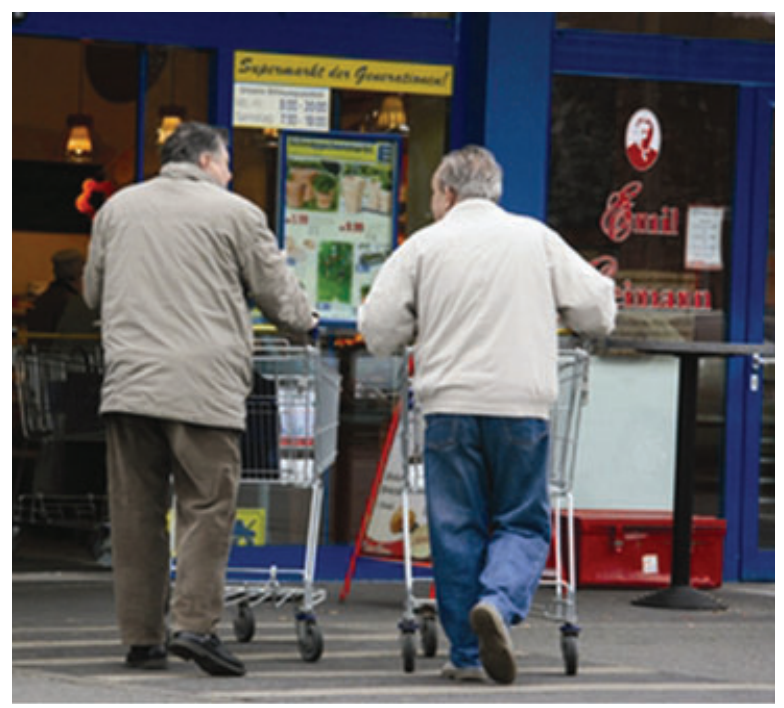

After having noticed the success of the Adeg senior supermarket, the Edeka chain soon followed. In December 2004, a "Supermarkt der Generationen" (Figure 1) was opened in Chemnitz (Stöcker, 2009).

\section{Case Study 2: Kaiser's Generations Market}

Following the successful Adeg story, in 2006 the German Tengelmann Group entered this new territory as well by opening its first senior supermarket in Berlin (Arnold \& Krancioch, 2008; Bradley, 2007). The Kaiser's chain (a subsidiary of Tengelmann Group) opened a "Kaiser's Generations Market," adapted to the needs and wants of older customers (Figure 2).

\section{Evaluation of Both Stores}

Table 2 makes clear that both supermarkets translate the earlier discussed physical and social shopping needs and wants of silver shoppers into retail practice.

Concerning the external store environment, both supermarkets pay attention to the aspect of transportation to and from the store. Edeka, for instance,
Figure 2. Kaiser's Generations Market (used with permission from John MacDougall/AFP/Getty Images).

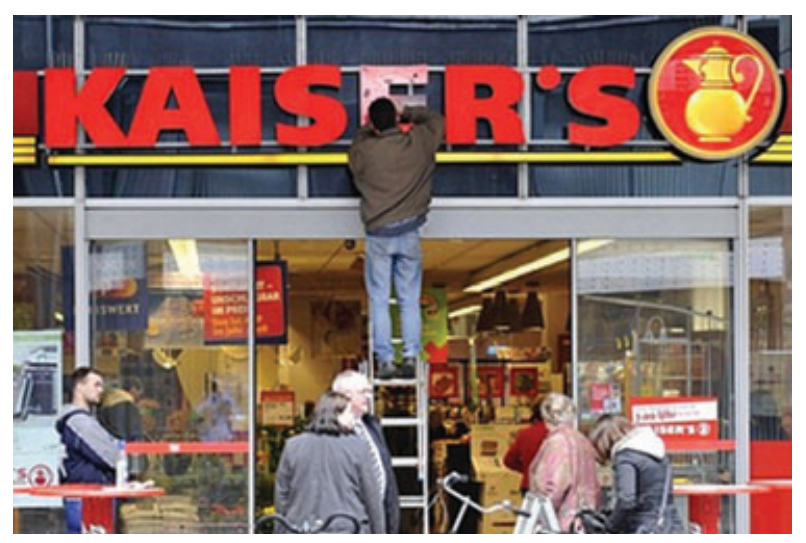

equipped its parking place with broad parking spots, close to the store (Beckers, 2008).

Concerning the internal store environment, both stores' design focused on creating a good overview and obvious in-store orientation. Different instore signs, identifying product groups and product illustrations, lower shelves' height, and wider aisles all are interior and retail designers' tools for understanding this objective (Figure 3).

In order to prevent consumers from falling, both stores have been equipped with non-skid floors. Also, for Adeg as well as for Kaiser's, good legibility is a priority in price and product information. As a result, both supermarkets provide large price labels, which are clearly displayed. By giving proper attention to the lighting concepts, both stores succeeded as well in creating a pleasant shopping atmosphere.

In addition to applying to the discussed needs and wants of older consumers, both stores also do special efforts to integrate functional and social features in the store which particularly are appreciated by the mature market. "Adeg Aktiv Mark 50+," for instance, added magnifying glasses hanging from different shelves in the store, to help people having trouble reading labels. 
PETERMANS AND VAN CLEEMPOEL

Table 2. Evaluation scheme

\begin{tabular}{|c|c|c|c|c|}
\hline Points of interest & & & Adeg & Kaiser \\
\hline Physical aspects & $\begin{array}{l}\text { External store environment } \\
\text { Internal store environment }\end{array}$ & $\begin{array}{l}\text { Mobility/locational } \\
\quad \text { considerations/accessibility } \\
\text { Shelves' height } \\
\text { Width of aisles } \\
\text { Brighter lighting } \\
\text { Non-skid floors } \\
\text { Larger price labels, clearly displayed } \\
\text { Friendly personnel-consumer } \\
\quad \text { interaction/good service } \\
\text { Rest areas in the store with possibility } \\
\quad \text { to socialize with others }\end{array}$ & $\begin{array}{l}\sqrt{ } \\
\sqrt{ } \\
\sqrt{ } \\
\sqrt{ } \\
\sqrt{ } \\
\sqrt{ } \\
\sqrt{ } \\
\sqrt{ }\end{array}$ & $\begin{array}{l}\sqrt{ } \\
\sqrt{ } \\
\sqrt{ } \\
\sqrt{ } \\
\sqrt{ } \\
\sqrt{ } \\
\sqrt{ } \\
\sqrt{ }\end{array}$ \\
\hline
\end{tabular}

In Kaiser's stores, magnifying glasses are fixed to the shopping carts (Figures 4 and 5).

Next to investing in friendly personnel in general, Adeg decided to match the target market with their employees, which are all over 50. These people all are paid about $10 \%$ more than their younger counterparts. As a result, the employees are highly motivated, and older customers seem to highly value this initiative (Ralli, 2003).

"Kaiser's Generations Market" also invested in extra functional and social facilities. Kaiser's, for instance, developed curvy seated carts with a built-in place to rest and magnifying glasses hanging from the cart (Figure 6).

Next to this extra investment in functionality, Kaiser's anticipated on the knowledge that silver shoppers value intangible in-store experiences and often go shopping as a way of socializing with their friends by creating a so-called senior corner. This in-store rest area is furnished with comfortable leather couches, where consumers are able to socialize and meet other people over coffee and cake in a relaxed atmosphere (Robinson, 2008). Kaiser's senior corner in addition is prettified by installing a massage couch, an information monitor, and Internet access (Arnold \& Krancioch, 2008).
Figure 3. Edeka interior space (used with permission from Stephanie Beckers).

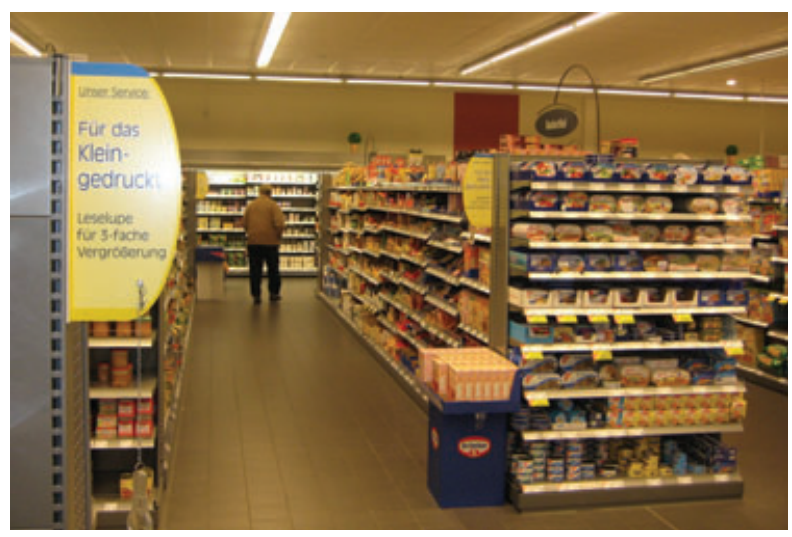

The positive effect on the general turnover, an explicit selection criterion for including these specific case studies, shows that both stores indeed have a strong appeal. A more thorough review of the annual reports of both supermarket chains and relevant publications in professional journals demonstrates that this "successfulness" is apparent in several aspects. First, Kaiser's chain communicated that sales were $25 \%$ above anticipated figures, and longtime customers seemed happy as well (Robinson, 2008; Sims, 2008). The turnover of Adeg's senior supermarkets increased in the same way: their figures rose by $20 \%$ compared to that of other stores of the 


\section{Figure 4. Edeka's magnifying glasses (used with permission from Stephanie Beckers).}

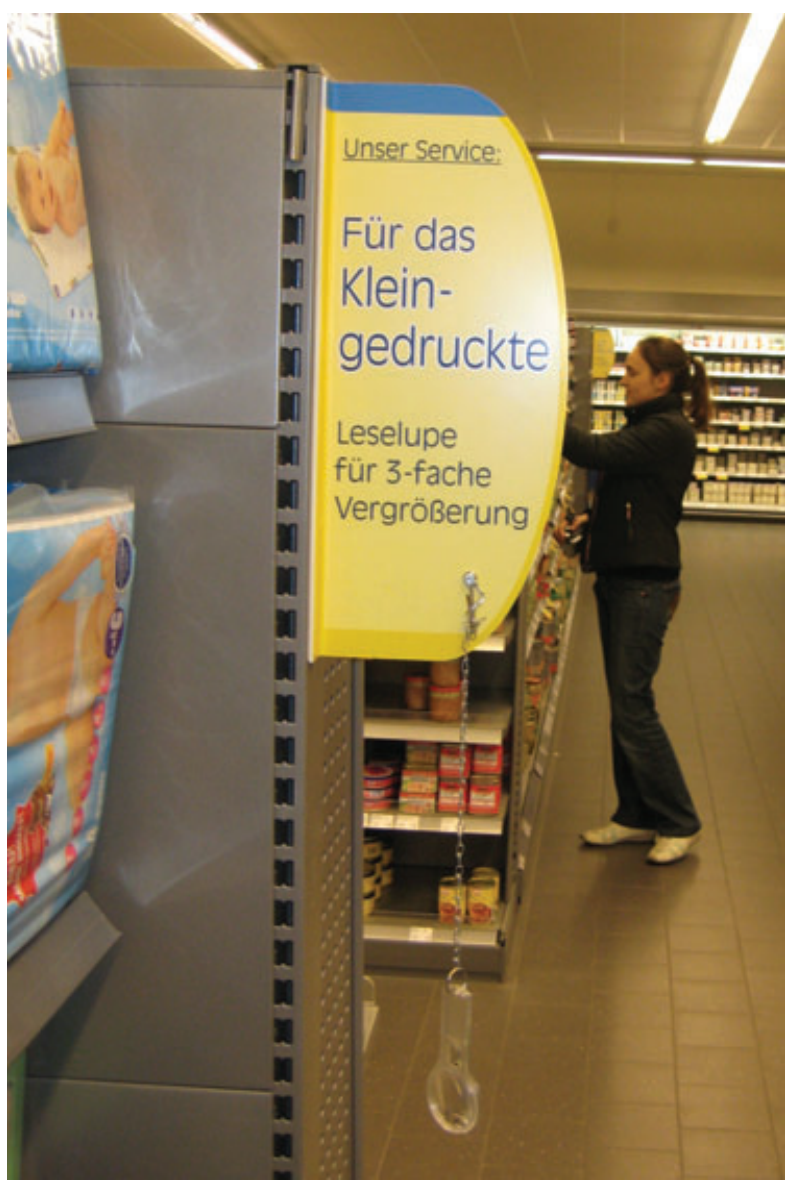

same chain (Smit, 2004). A second indicator for the successfulness of the design formula is the diffusion of the retail store concept. Soon after the opening of the pilot store, Adeg opened similar supermarkets in Austria and started redesigning their existing supermarkets. Later on, also in Germany, similar senior supermarkets were opened. In addition, Adeg noticed that also other age groups were responding positively to the store's (universally designed) product selection and layout enhancements. Consequently, from that moment on, Adeg no longer speaks of an "Aktiv 50+ Mark," but of a "Supermarket der Generationen" (Anderson, 2003; Edeka, n.d.). Soon
Figure 5. Kaiser's magnifying glasses (used with permission from Edeka and Tengelmann).

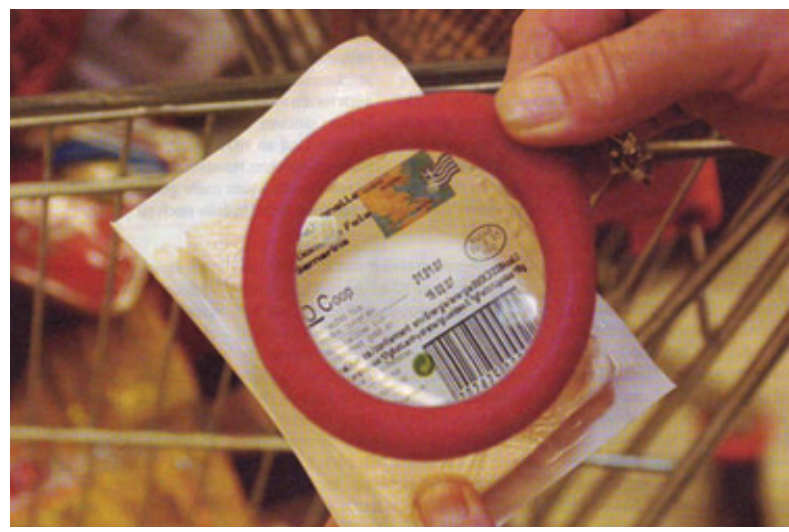

Figure 6. Curvy seated cart, Kaiser's Generations Market (used with permission from Edeka and Tengelmann).

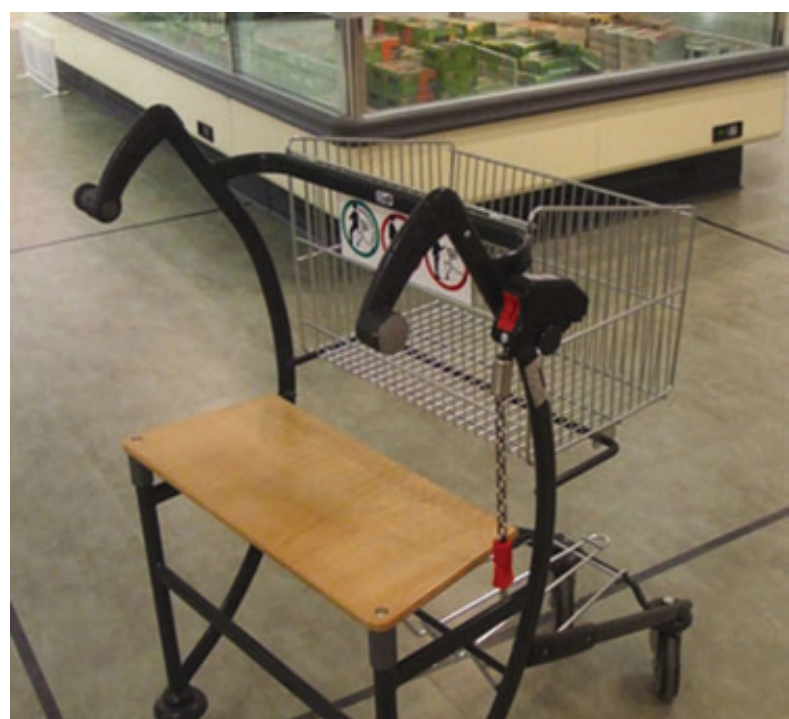

after the opening of Kaiser's "Generations Market" and noticing the success of the retail formula, the Tengelmann group in 2006 launched the "black, red, and gold" concept. Stores of the chain, designed according to this concept, are known to specifically attach great importance to functional and social 
The design alterations in supermarkets . . . have illustrated how a proper, specifically designed retail environment which pays particular attention to implementing an appropriate social approach, can strongly enhance shopping experiences for the mature market.

aspects of customers' shopping experiences by, for instance, offering appealing customer services. One hundred stores in the meantime have been converted to this new concept (The Tengelmann Group, 2008).

The Adeg and Kaiser's success stories seem to inspire other retail chains: recently, news spread out that British Tesco chain is thinking about opening a "senior supermarket" in Newcastle (Hurst, 2008; Robinson, 2008; Sims, 2008).

\section{Conclusion}

This study indicates that the "graying population" offers an enormous opportunity for marketers, retailers, designers, and consumer researchers alike. The literature review demonstrated clearly that the particular profile, status, and economic situation of today's mature market explains the concrete, functional, and social needs and wants of this consumer group in a retail environment. Since retailers in the current economy have to deliver value to the consumer, they truly have to focus on consumers' desires in the marketplace. Taking the theoretical body of knowledge into account, the authors decided to search for successful European case studies to discover how the design of retail stores can be adapted to meet older consumers' needs and wants. By judging the selected cases of "Adeg Aktiv Markt 50+" and "Kaiser's Generations Market" against the theoretically discussed points of interest, the authors learned that the functional and social enhancements of both stores appear to have resulted in loyal consumers. The design alterations in supermarkets of both chains have illustrated how a proper, specifically designed retail environment which pays particular attention to implementing an appropriate social approach can strongly enhance shopping experiences for the mature market. The presence of wider aisles, non-skid floors, brighter lighting, lower shelf heights, and clearly displayed and readable product labels and price tags are concrete illustrations of functional aspects which were specifically addressed to meet the needs of mature users in both case studies. Both supermarkets provided good service and incorporated in-store rest areas, which illustrates how a willingness to invest in those social aspects valued highly by silver shoppers proves worth the effort. Since making these design alterations the turnover of the Adeg senior supermarkets has increased by $20 \%$. The sales of Kaiser's senior supermarkets are $25 \%$ above anticipated figures. This illustrates that understanding and responding on a managerial level to silver shoppers' needs and wants is highly beneficial. Adeg's and Kaiser's adapted branding strategy also appears to have worked. However, the successful translation of older consumers' functional and social needs and wants into retail practice does not mean that the choice and quality of food available in the store can be neglected (Hare, 2003).

However, cultural dimensions seem to influence retailer interest in this consumer segment. For instance, in the Netherlands, supermarkets are less interested in investing in the mature market (Retailnews.nl, 2008, 2009). Therefore, it would be revealing to study how cultural and possible other conditions influence retailers' willingness to invest in these kinds of initiatives. To our knowledge, there is no research on this question.

This article focused on a comparison of two descriptive case studies of supermarkets. Longitudinal attentiveness has not been addressed and can be considered as a limitation of the study. As a result, it would be worthwhile expanding the number of supermarket case studies and it would be valuable to study other kinds of retail settings for a longer period of time. In addition, a quantitative study to investigate the response of older consumers to the adaptations made by senior supermarkets would result in a more thorough investigation. Finally, the literature review revealed that much research has already been done in the field of retail design and retail atmospherics. However, research that combines knowledge of universal design and retail design is rare. Taking into account the growing number of elderly people in Europe's demographics, this research domain will predictably become more popular. 


\section{References}

Ahmad, R. (2003). Benefit segmentation: a potentially useful technique of segmenting and targeting older consumers. International Journal of Market Research, 45(3), 373-388.

Anderson, G. (2003). The seniors' market. Retrieved October 10, 2008, from http://www.retailwire.com/Discussions/ Dngl_Discussion.cfm?doc_ID=9517.

Arabaci, D. (2008). All change as Germany's population goes grey. Berlin: European Union Business. Retrieved October 24 2008, from http://www.eubusiness.com/news-eu/ $1209259921.85 /$.

Areni, C., \& Kim, D. (1994). The influence of in-store lighting on consumers' examination of merchandise in a wine store. International Journal of Research in Marketing, 11, 1 17-125.

Armstrong, L. (2005). Remodeling for the future. Business Week, July 25, 104-106.

Arnold, G., \& Krancioch, S. (2008). Current strategies in the retail industry for Best-Agers. In F. Kohlbacher \& F. Herstatt (Eds.), The silver market phenomenon. Berlin: Springer.

Babin, B., \& Attaway, J. (2000). Atmospheric affect as a tool for creating value and gaining share of customer. Journal of Business Research, 49, 91-99.

Balazs, A. (1994). The eldermall: exploring new ways to position the aging retail shopping center for aging consumers. Journal of Shopping Center Research, 1, 39-64.

Bartos, R. (1990). Older people in the United States-the invisible consumer market. In S. Buck (Ed.), The 55-plus market. Exploring a golden business opportunity. London: McGraw-Hill.

Beckers, S. (2008). Revolutie in het distributiebeleid van supermarkten. Een onderzoek naar de noodzakelijke aanpassingen aan de toenemende vergrijzing. Hasselt: Universiteit Hasselt.

Bloemer, J., \& de Ruyter, K. (1 998). On the relationship between store image, store satisfaction and store loyalty. European Journal of Marketing, 32(5/6), 499-513.

Bone, P. (1991). Identifying mature segments. Journal of Services Marketing, 5(1), 47-61.

Borg, P. (2009). Eurostat news release-household budget survey 2005 in the EU27. [email correspondence] received $08 / 06 / 2009$

Bradley, K. (2007). Super values. The design of a Berlin supermarket addresses the needs of an aging population. Retrieved May 19, 2009, from http://www.metropolismag.com/story/ 20070620/super-values.

Brigham, B. (2005). Trends in retail design. Informedesign, 3(8). Retrieved January 5, 2009 from http://www. informedesign. umn.edu/_news/aug_v03-p.pdf.

Brock, J. (n.d.). The aging of America. The rising tide. Retrieved January 28, 2008, from http://www.robinson.gsu.edu/ magazine/mature.html.
Buck, S. (1990). Turning an old problem into a new marketing opportunity. In S. Buck (Ed.), The 55-plus market. Exploring a golden business opportunity. London: McGraw-Hill.

Burnett, J. (1996). Comparing the patronage selection criteria of the elderly: chronological age versus dependency. The International Review of Retail, Distribution and Consumer Research, 6(3), 243-257.

Burt, S., \& Gabbott, M. (1995). The elderly consumer and non-food purchase behaviour. European Journal of Marketing, 29(2), 43-57.

Chu, A., \& Lam, M. (2002). Store environment of fashion retailers: a Hong Kong perspective. In T. Hines \& M. Bruce (Eds.), Fashion marketing: contemporary issues. Boston, $M A$ : Butterworth-Heinemann

Colla, E. (2004). The outlook for European grocery retailing: competition and format development. International Review of Retail, Distribution and Consumer Research, 14(1), 47-69.

Curch, L., \& Thomas, A. (2006). Shopper's Paradise Lost: shopping by elderly adults in the age of big box businesses. New York: Center for Social Science Research, State University of New York.

Edeka (n.d.). Supermarkt der Generationen. [email correspondence] received from Stöcker, U., at 09/06/2009.

Esbjerg, L., \& Bech-Larsen, T. (2009). The brand architecture of grocery retailers: setting material and symbolic boundaries for consumer choice. Journal of Retailing and Consumer Services, $16,414-423$

Eurostat Press Office, (2008). Household Budget Survey 2005 in the EU27. Households dedicated more than half of their expenditure to housing and food. Retrieved May 15, 2009, from http:// europa.eu/rapid/pressReleasesAction. do? reference=STAT/08/ 88\&format=HTML\&aged=0\&language $=E N \&$ guilanguage $=e n$.

Fiore, A., \& Kim, J. (2007). An integrative framework capturing experiential and utilitarian shopping experience. International Journal of Retail \& Distribution Management, 35(6), 42 1-442.

Gabriel, J. (1990a). The size and nature of the ageing population. In S. Buck (Ed.), The 55-plus market. Exploring a golden business opportunity. London: McGraw-Hill.

Gabriel, J. (1990b). Portraits of the over-55s in the United Kingdom. In S. Buck (Ed.), The 55-plus market. Exploring a golden business opportunity. London: McGraw-Hill.

Gentile, C., Spiller, N., \& Noci, G. (2007). How to sustain the customer experience: an overview of experience components that co-create value with the customer. European Management Journal, 25(5), 395-410.

Giannakouris, K. (2008). Ageing characterises the demographic perspectives of the European societies. EUROSTAT, Statistics in focus. Luxembourg: Office for Official Publications of the European Communities.

Greer Huss Pace, M. (2006). Preferences for universal design features in apparel retail stores by older female apparel customers. Columbus, $\mathrm{OH}$ : Ohio State University. 
Guy, C. (1998a). Classifications of retail stores and shopping centres: Some methodological issues. GeoJournal, 45, 255-264.

Guy, C. (1998b). Controlling new retailing spaces, the impress of planning policies in Western Europe. Urban Studies, 35(5-6), 953-979.

Hare, C. (2003). The food-shopping experience: a satisfaction survey of older Scottish consumers. International Journal of Retail \& Distribution Management, 31 (5), 244-255.

Holbrook, M., \& Hirschman, E. (1982). The experiential aspects of consumption: consumer fantasies, feelings and fun. Journal of Consumer Research, 9, 132-140.

Hunt, M. (1992). The design of supportive environments for older people. Journal of Housing for the Elderly, 9(1-2), 127-140

Hurst, B. (2008). New store considered for senior shoppers. Retrieved October 10, 2008, from http://www. retailwire.com/ Discussions/Sngl_Discussion.cfm/13203.

Kim, Y., Kang, J., \& Kim, M. (2005). The relationships among family and social interaction, loneliness, mall shopping motivation, and mall spending of older consumers. Psychology \& Marketing, 22(12), 995-1015.

Kindleysides, J. (2007). An introduction to retail design. Retrieved June 16, 2007, from http://www. design-council.org.uk/ en/About-Design/Design-Disciplines/Retail-Design/ Recommended-reading/.

Kotler, P. (1973). Atmospherics as a marketing tool. Journal of Retailing, 49, 48-64

Kotler, P. (2001). Marketing management, Millenium Edition. Upper Saddle River, NJ: Pearson Education Company.

Lumpkin, J., \& Greenberg, B. (1982). Apparel-shopping patterns of the elderly consumer. Journal of Retailing, 58(4), 68-89.

Lumpkin, J., \& Hite, R. (1988). Retailers' offerings and elderly consumers' needs: do retailers understand the elderly? Journal of Business Research, 16, 313-326.

Mathur, A., \& Moschis, G. (2005). Antecedents of cognitive age: a replication and extension. Psychology \& Marketing, 22(12), 969-994

Mathwick, C., Malhotra, N., \& Rigdon, E. (2001). Experiential value: conceptualization, measurement and application in the catalog and Internet shopping environment. Journal of Retailing, 77, 39-56.

Meneely, L., Strugnell, C., \& Burns, A. (2009). Elderly consumers and their food store experiences. Journal of Retailing and Consumer Services, 16, 458-465.

Mogelonsky, M. (1995). Satisfying senior shoppers. American Demographics, 17(4), 4.

Moschis, G. (1992). Marketing to older adults: A handbook of information for strategy development. Westport, CT: Greenwood Press.

Moschis, G. (1996). Gerontographics: life-stage segmentation for marketing strategy development. Westport, CT: Quorum Books.
Moschis, G. (2003). Marketing to older adults: an updated overview of present knowledge and practice. Journal of Consumer Marketing, 20, 516-525.

Myers, H., \& Lumbers, M. (2006). Future of retail property Consumers over 55: Silver shoppers provide a golden opportunity. London: British Council of Shopping Centres.

Myers, H., \& Lumbers, M. (2008). Understanding older shoppers: A phenomenological investigation. Journal of Consumer Marketing, 25(5), 294-301.

Nijs, D., \& Peters, F. (2002). Imagineering. Het creëren van belevingswerelden. Amsterdam: Boom.

Null, R. A. (1989). Universal design for the elderly. Housing and Society, 16(3), 77-83

Oates, B., Shufeldt, L., \& Vaught, B. (1996). Lifestyle segmentation: what retail store attributes are important to the elderly? Retrieved February 25, 2008, from http://www.sbaer.uca.edu/research/sma/1996/pdf/05.pdf.

Pine, J., \& Gilmore, J. H. (1999). The experience economy: Work is theatre and every business a stage. Boston: Harvard Business School Press.

Pine, J., \& Gilmore, J. (2008). Authenticiteit. Wat consumenten echt willen. Den Haag: Academic Service.

Prahalad, C., \& Ramaswamy, V. (2004). The future of competition. Boston: Harvard Business School Press.

Ralli, T. (2003). International business; as Europe ages, a grocery chain extends a hand. The New York Times. Retrieved October 10, 2008, from http://query.nytimes.com/ gst/fullpage. $h$ tmleres=9BO3E 1 D7143EF934A $15751 \mathrm{ClA}$ $9659 \mathrm{C} 8 \mathrm{~B} 63 \&$ sec $=\&$ spon $=\&$ pagewanted $=1$.

Retailnews.nl (2008). Supermarkt laat seniorenmarkt links liggen. Retrieved November 13, 2008, from http://www.retailnews.nl.

Retailnews.nl (2009). Winkelier doet te weinig voor ouderen. Retrieved May 18, 2009, from http:/ / www. retailnews. $n$ l/nieuws $/$ ?id=23746.

Robinson, C. (2008). Tesco to adapt supermarket for pensioners. The Journal-ncjMedia Limited. Retrieved October 17, 2008 from http://www.journallive.co.uk/north-east-news/todaysnews/tm_headline=tesco-to-adapt-supermarket-forpensioners.html.

Schiffman, L., \& Sherman, E. (1991). Value orientations of new-age elderly: the coming of an ageless market. Journal of Business Research, 22, 187-194.

Schmidt, R., Segal, R., \& Cartwright, C. (1994). Two-stop shopping or polarization? Whither UK grocery retailing? International Journal of Retail and Distribution Management, 22(1), $12-19$

Sherman, E., Schiffman, L., \& Mathur, A. (2001). The influence of gender on the new-age elderly's consumption orientation. Psychology \& Marketing, 18(10), 1073-1089.

Sims, P. (2008). Tesco reveals Britain's first 'pensioner-friendly' supermarket-with magnifying glasses and seats on trolleys. The 
Daily Mail. Retrieved October 17, 2008, from

http://www.dailymail.co.uk/news/article-1050195/Tescoreveals-Britains-pensioner-friendly-supermarket-magnifyingglasses-seats-trolleys.html.

Smit, P. (2004). Oostenrijkse seniorensuper succesvol. Retrieved January 24, 2008, from http://www.elsevierretail.nl/ 1042253/RetailHome/Nieuws/Food/KopieVanFood nieuwsbericht/OostenrijkseSeniorensuperSuccesvol.htm

Stöcker, U. (2009). Image Adeg Aktiv Markt 50+. [email correspondence] received at 09/06/2009.

Stroud, D. (2005). The 50-plus market. Why the future is age neutral when it comes to marketing \& branding strategies. London: Kogan Page.

Summers, T., \& Herbert, P. (200 1). Shedding some light on store atmospherics: influence of illumination on consumer behaviour. Journal of Business Research, 54(2), 145-150.

Sweeney, J., \& Soutar, G. (2001). Consumer perceived value: the development of a multiple item scale. Journal of Retailing, 77, 203-220.

Szmigin, I., \& Carrigan, M. (200 1). Learning to love the older consumer. Journal of Consumer Behaviour, 1 11), 22-34

The Consumer Council, (n.d.). Silver Service? Are supermarkets meeting the needs of older shoppers? Belfast: General Consumer Council for Northern Ireland.

The Tengelmann Group (2008). Balance sheets and notes 2007-2008. Retrieved October 1, 2009, from http:// www.tengelmann.de/fileadmin/pdf/2008/GB_Balance Sheet.pdf.

Turley, L., \& Milliman, R. (2000). Atmospheric effects on shopping behaviour: a review of the experimental evidence. Journal of Business Research, 49, 193-211.

Underhill, P. (1996). Seniors in stores. American Demographics, 18(4), 44-48.

Underhill, P. (1999). Why we buy what we buy. New York: Simon \& Schuster.

United Nations. (2001). World population ageing: 1950-2050, Department of economic and social affairs. Population division. New York: United Nations.

United Nations (2007). Demographic Yearbook 2004. Annuaire démographique 2004. Fifty-sixth issue. Cinquante-sixième edition. Department of Economic and Social Affairs. Département des affaires économiques et sociales. New York: United Nations.

Van Amerongen, R., \& Christiaans, H. (2004). Retail \& interior design. Rotterdam: Episode Publishers.

Van Ossel, G., \& Versteylen, C. (2003). Retailer branding: de winkel wordt merk! Gent: Vlerick Leuven Gent Management School.

Van Tongeren, M. (2003). Retail branding. From stopping power to shopping power. Amsterdam: BIS Publishers.
Van Tongeren, M. (2004). Retail Branding. In R. van Amerongen \& H. Christiaans (Eds.), Retail \& interior design. Rotterdam: Episode Publishers

Vargo, S., \& Lusch, R. (2004). Evolving to a new dominant logic for marketing. Journal of Marketing, 68(1), 1-17.

Weiiters, B., \& Geuens, M. (2003). Segmenting the senior market: professional and social activity level. Vlerick Working Papers 2003/03. Gent: Vlerick Leuven Gent Management School.

Wilson, L., Alexander, A., \& Lumbers, M. (2004). Food access and dietary variety among older people. International Journal of Retail \& Distribution Management, 32(2), 109-122.

Yin, R. (2002). Case study research, design and methods (2nd ed.). Thousand Oaks: Sage Publications.

Yin, R. (2003). Applications of case study research. (2nd ed.) Thousand Oaks: Sage Publications.

Yin, R. (2009). Case study research. Design and methods. (4th ed.). Los Angeles: Sage Publications.

\section{Notes}

1The term "silver shoppers" is also used in a publication by Myers and Lumbers (2006).

${ }^{2}$ Figures, for instance, indicate that in Europe, over-55s generally possess more than $60 \%$ of all financial savings (Buck, 1990).

3 Other authors refer to this variable as "cognitive age" (Sherman, Schiffman, \& Mathur, 2001; Mathur \& Moschis, 20051.

${ }^{4}$ According to the authors' view, intangible retail design and atmospherics (as used by Kotler, 1973) are similar to one another.

${ }^{5}$ The functional and physical needs and wants of silver shoppers in a retail store will be further discussed in "Universal design: importance of physical aspects in the retail store environment."

${ }^{6}$ The social and emotional aspects silver shoppers find particularly appealing in a retail store will be further discussed in "Experience economy: importance of social aspects in the retai store environment."

${ }^{7}$ Although Null (1989) stated that the concept of "universal design" is used to describe an environment that is accessible and aesthetically pleasing to people of all ages and abilities, in this article, the term is used to describe an environment that is accessible and pleasing to the mature market.

${ }^{8}$ The Eurostat publication (2008) pointed out that the rest of household expenditure was mainly dedicated to clothing and footwear $(5.7 \%)$, restaurants and hotels $(5.3 \%)$, health $(3.4 \%)$, communications (3.3\%), and education (1.0\%). 